University of Nebraska - Lincoln

DigitalCommons@University of Nebraska-Lincoln

Faculty Publications in the Biological Sciences

Papers in the Biological Sciences

$11-1989$

\title{
Can Genetically Engineered Crops Become Weeds?
}

Kathleen H. Keeler

University of Nebraska - Lincoln, kkeeler1@unl.edu

Follow this and additional works at: https://digitalcommons.unl.edu/bioscifacpub

Part of the Agricultural Science Commons, Agronomy and Crop Sciences Commons, Botany

Commons, Genetics Commons, Plant Breeding and Genetics Commons, and the Terrestrial and Aquatic

Ecology Commons

Keeler, Kathleen H., "Can Genetically Engineered Crops Become Weeds?" (1989). Faculty Publications in the Biological Sciences. 318.

https://digitalcommons.unl.edu/bioscifacpub/318

This Article is brought to you for free and open access by the Papers in the Biological Sciences at DigitalCommons@University of Nebraska - Lincoln. It has been accepted for inclusion in Faculty Publications in the Biological Sciences by an authorized administrator of DigitalCommons@University of Nebraska - Lincoln. 


\title{
Can Genetically Engineered Crops Become Weeds?
}

\author{
Kathleen Keeler \\ Associate Professor, Ecology and Evolutionary Biology \\ School of Biological Sciences, University of Nebraska-Lincoln, Lincoln, Nebraska, USA
}

What is a hazardous genetically engineered organism? We still don't have the answer to that question. Indeed, opinions vary widely as to what actually constitutes a hazardous-or safe-organism, what the limits of risk are, and what constitutes adequate proof of same ${ }^{1-6}$. But we do know that for environmentally released genetically engineered organisms to present problems, all of the following are required: possessing a gene for a hazardous trait; survival in the environment; multiplication of the organism; contact with species or biological systems that can be injured; and causing harm ${ }^{1,8}$. If any of these are missing, there should be no harm from the release.

Genetically engineered crop plants are some of the safer of the new agricultural "breed:" they are not generally a health hazard to people or animals; they are raised under close supervision; many are harvested at the end of the season; and plants are not very mobile ${ }^{1,2,7,10}$. While recent findings indicate that lateral transfer of genes between plants and their various parasites can occur ${ }^{1,11}$, and the importance of this form of genetic exchange is unknown, the greatest hazard expected from plant agricultural biotechnology is the anticipated production of serious weeds $1,2,7,10,12$. Weeds reduce agricultural productivity by at least 12 percent, a figure that has increased by 50 percent since the $1940 \mathrm{~s}^{13}$. Thus, if even more weeds emerge, they could seriously affect economic productivity. In addition, a serious weed might invade natural ecosystems, causing massive changes $^{13,14}$. Creating new weeds is not a trivial hazard $1,2,3,7,10,12$.

\section{What Is a Weed?}

Historically, weeds have evolved from: wild colonizers by selective modification to invade human-disturbed habitats; the wild relatives of crop plants by genetic exchange with crops; and crops plants by selection for weedy traits $^{15}$. Of these, the first is unaffected by a shift to genetically engineered crop plants and will not be considered here. The second, exchange with wild relatives, is a widely acknowledged risk $^{1,2,9}$. It is unlikely that plants with weedy local relatives will be released in the near future ${ }^{2,9,10}$. Except for noting that most species have weedy wild relatives somewhere ${ }^{2}$, I will not further consider this source of new weeds.

Consequently, this paper focuses on the evolution of weeds from crop plants themselves. What we know of weed biology is used to approach the following questions: what characteristics distinguish weeds from other plants; the distribution of these traits among weeds, non-weeds, and crop plants; and how easily weediness might evolve in crop plants.

There is a general consensus about plant characteristics associated with weediness ${ }^{16-20}$. Approximately half of these characteristics are known to be determined by single genes in some species; for many, substitution of a single dominant allele will produce a weedy phenotype in a plant that previously lacked it ${ }^{7}$. Thus, evolving a weedy phenotype need not be difficult. However, producing a weedy phenotype may require multiple genetic changes. If, for example, most crops possess none of the weedy traits, and most economically important weeds possess 10 or 12, then for crops to evolve serious weediness would require the simultaneous substitution of alleles at 10 to 12 loci, This change is highly improbable, especially for annual crops raised from commercial seed stocks. On the other hand, if many serious weeds possess only five of these weedy traits, and most crop species have at least three of them, then the evolution of significant weediness under many ordinary agricultural practices may be probable, Thus, data on the average risk of evolution of serious new weeds canat least provisionally - be gathered by comparing the array of weedy characteristics found in weeds, crops, and "normal" plants. One is still generalizing, but with more precision. As a method for testing these ideas, I have I scored the distribution of the traits designated as characteristics of weeds ${ }^{16-18}$ in three sets of plants: weeds, crops, and a random selection from a flora. The point of the analysis is to critically evaluate the likelihood of evolution of plants with weedy phenotypesfrom genetically engineered crop plants, based on the distribution of traits favoring weediness. 
TABLE 1. WEEDY CHARACTERISTICS OF WORLD'S WORST WEEDS

\begin{tabular}{|c|c|c|c|c|c|c|c|c|c|c|c|c|c|c|c|c|}
\hline $\begin{array}{l}\text { Plant species } \\
\text { (Family) }\end{array}$ & $\begin{array}{c}\text { Germ } \\
\text { Breadth }^{\mathrm{a}}\end{array}$ & Discont. ${ }^{b}$ & $\begin{array}{c}\text { See } \\
\text { Longev. }^{c}\end{array}$ & $\begin{array}{c}\text { Rapid } \\
\text { Growth }^{\mathrm{d}}\end{array}$ & Cont. Seed ${ }^{2}$ & Self $^{f}$ & Visitors8 & $\begin{array}{c}\text { Seed } \\
\text { Output }^{\mathrm{h}}\end{array}$ & $\begin{array}{l}\text { Seed } \\
\text { Prod. }^{i}\end{array}$ & $\begin{array}{c}\text { Disper- } \\
\text { sali }\end{array}$ & $\begin{array}{c}\text { Veg. } \\
\text { Reprod. }^{\mathrm{k}}\end{array}$ & Brittle $^{1}$ & $\begin{array}{l}\text { Compete } \\
\text { Well }^{\mathrm{m}}\end{array}$ & $\begin{array}{c}\text { Eco- } \\
\text { types? }^{\mathrm{n}}\end{array}$ & $\begin{array}{l}\text { Poly- } \\
\text { ploid }\end{array}$ & Cultivated \\
\hline $\begin{array}{l}\text { Cyperus rotundus } \\
\text { (Poaceae) }\end{array}$ & + & + & + & + & \pm & + & + & + & + & + & + & + & + & + & ? & 1 \\
\hline $\begin{array}{l}\text { Cynodon dactylon } \\
\text { (Poaceae) }\end{array}$ & + & $?$ & + & ? & ? & $?$ & $+?$ & - & \pm & - & + & + & - & + & ? & 5 \\
\hline $\begin{array}{l}\text { Echinochloa crusgalli } \\
\text { (Poaceae) }\end{array}$ & + & + & + & + & + & ? & $+?$ & + & $+?$ & + & NA & NA & + & + & ? & 6 \\
\hline $\begin{array}{l}\text { Echinochloa colonum } \\
\text { (Poaceae) }\end{array}$ & + & + & + & + & + & ? & + & + & $+?$ & + & NA & NA & + & $-?$ & $?$ & 6 \\
\hline $\begin{array}{l}\text { Eleusine indica } \\
\text { (Poaceae) }\end{array}$ & + & + & ? & + & + & ? & + & + & $+?$ & + & NA & NA & - & - & ? & 5 \\
\hline $\begin{array}{l}\text { Sorghum halapense } \\
\text { (Poaceae) }\end{array}$ & + & - & + & $+?$ & - & ? & + & + & + & + & + & + & + & + & - & 5 \\
\hline $\begin{array}{l}\text { (Poaceae) } \\
\text { (Poaceata) }\end{array}$ & + & - & - & $?$ & $?$ & + & + & + & + & + & + & + & + & + & $?$ & 6 \\
\hline $\begin{array}{l}\text { Portulaca oleracea } \\
\text { (Portulaceae) }\end{array}$ & + & + & + & $+?$ & + & + & + & + & + & + & + & NA & - & + & ? & 7 \\
\hline $\begin{array}{l}\text { Chenopodium album } \\
\text { (Chenopodiaceae) }\end{array}$ & + & + & + & $+?$ & $+?$ & ? & + & + & + & - & NA & $\mathrm{NA}$ & + & + & ? & 3,5 \\
\hline $\begin{array}{l}\text { Digitaria } \\
\text { sanguinenesis } \\
\text { (Poaceae) }\end{array}$ & + & + & ? & + & + & ? & + & + & $+?$ & $+?$ & NA & + & + & + & ? & 5 \\
\hline $\begin{array}{l}\text { Convolvulus arvensis } \\
\text { (Convolvulaceae) }\end{array}$ & + & $+?$ & + & $?$ & ? & ? & + & ? & $?$ & + & + & + & - & + & ? & 4 \\
\hline $\begin{array}{l}\text { Avena fatua } \\
\text { (Poaceae) }\end{array}$ & + & + & + & $+?$ & + & $+?$ & + & \pm & $+?$ & - & NA & NA & + & + & - & 2 \\
\hline $\begin{array}{l}\text { Amaranthus } \\
\text { hydbridus } \\
\text { (Amaranthaceae) }\end{array}$ & + & $?$ & ? & $+?$ & $+?$ & - & + & + & $+?$ & $-?$ & NA & NA & + & ? & ? & 3 \\
\hline $\begin{array}{l}\text { Amaranthus spinosus } \\
\text { (Amaranthaceae) }\end{array}$ & + & + & + & + & $+?$ & - & + & + & $?$ & $-?$ & NA & NA & - & + & ? & 7 \\
\hline $\begin{array}{l}\text { Cyperus esculentus } \\
\text { (Cyperaceae) }\end{array}$ & + & + & $?$ & - & ? & - & + & + & + & - & + & + & - & + & ? & 2 \\
\hline $\begin{array}{l}\text { Paspalum } \\
\text { conjugatum } \\
\text { (Poaceae) }\end{array}$ & \pm & $?$ & ? & ? & + & ? & + & + & + & - & + & $-?$ & + & ? & ? & 5 \\
\hline $\begin{array}{l}\text { (Rottboellia exalata } \\
\text { (Poaceae) }\end{array}$ & + & + & $?$ & + & + & ? & ? & + & $+?$ & - & NA & NA & + & + & ? & 5 \\
\hline
\end{tabular}

${ }^{\mathrm{a} G e r m i n a t i o n ~ r e q u i r e m e n t s ~ f u l f i l l e d ~ i n ~ m a n y ~ e n v i r o n m e n t s ; ~}{ }^{b}$ Internally controlled discontinuous germination; ${ }^{\mathrm{c}}$ Long-lived seed; ${ }^{\mathrm{d}}$ Rapid growth to flowering; eContinuous seed production as long as growing conditions permit; fFacultatively self-compatible; gIf outcrossed, uses wind or unspecialized insects; ${ }^{\text {h}}$ Very high seed output possible; iSome seeds produced in many environments: tolerant; SSeeds adapted for short and long distance dispersal; ${ }^{\text {If }}$ perennial, vegetative growth or regeneration from fragments; If perennial, hard to uproot; ${ }^{\mathrm{m}}$ Good competitor: rosette, choking growth, allelochemics; ${ }^{\mathrm{n}}$ Form ecotypes; Cultivated: 1 , planted as soil binder; 2 , cultivated; 3 , gathered as potherb; 4 , gathered as medicinal plant; 5 , raised as pasture; 6 , used in mats; 7 , not used by humans. 


\section{Methods}

The 13 plant characteristics typical of weedy species that were noted by Baker ${ }^{16}$ are still generally accepted as the key adaptive characteristics that contribute to success in a weedy lifestyle ${ }^{17-20}$. The number of weedy traits possessed by plants of different categories of weediness and economic importance are evaluated as follows:

Two lists of weeds were generated. The first list contained the plants that make up the ordered set of "The World's Worst Weeds"21 (Table 1). Twenty additional species were drawn at random from the 48 unordered plants listed as the rest of the world's worst weeds ${ }^{21}$ to create a second sample of weedy species (data not included in tabular form).

Comparable data on nonweedy plants are difficult to obtain. Floras are natural assemblages of plants, but most flora give little more than information that is needed for identification. The Biological Flora of the British Isles, which has appeared in the Journal of Ecology, volume 29 (1941) to present, is an attempt to publish in-depth ecological information about all the plants in a region. Rabinowitz et al. ${ }^{22}$ analyzed the Biological Flora, finding significant overrepresentation of common species, but no bias toward rare plants. Herbs may be overrepresented, which is an advantage for a comparison to weeds. At thesame time, the Biological Flora may include an excess of weedy species, since they are common.

A sample of 20 species was drawn from the Biological Flora of the British Isles, 1942-1985 (142 entries, less than 10 percent of the actual flora), using random numbers (data not included in tabular form).

A list of 20 crop plants was developed using Harrison et al. ${ }^{23}$ and Holm et al. ${ }^{21}$, with the stipulation that no two members of the same genus be included (Table 2). Plants were classified as having or lacking the characteristics of an ideal weed based on the information in those and other sources $^{24-26}$.

\section{Weeds}

Baker has long claimed that there are no serious contenders for the "ideal weed"16,17 but, as scored here, Cyperus rotundus comes extremely, close (Table 1). This plant has all of the characteristics of an "ideal weed" except possibly the ability to reproduce continuously ${ }^{21}$. No other species possesses as many of the weedy characteristics. But the 17 worst weeds 
TABLE 2. CHARACTERISTICS OF TWENTY CROP PLANTS

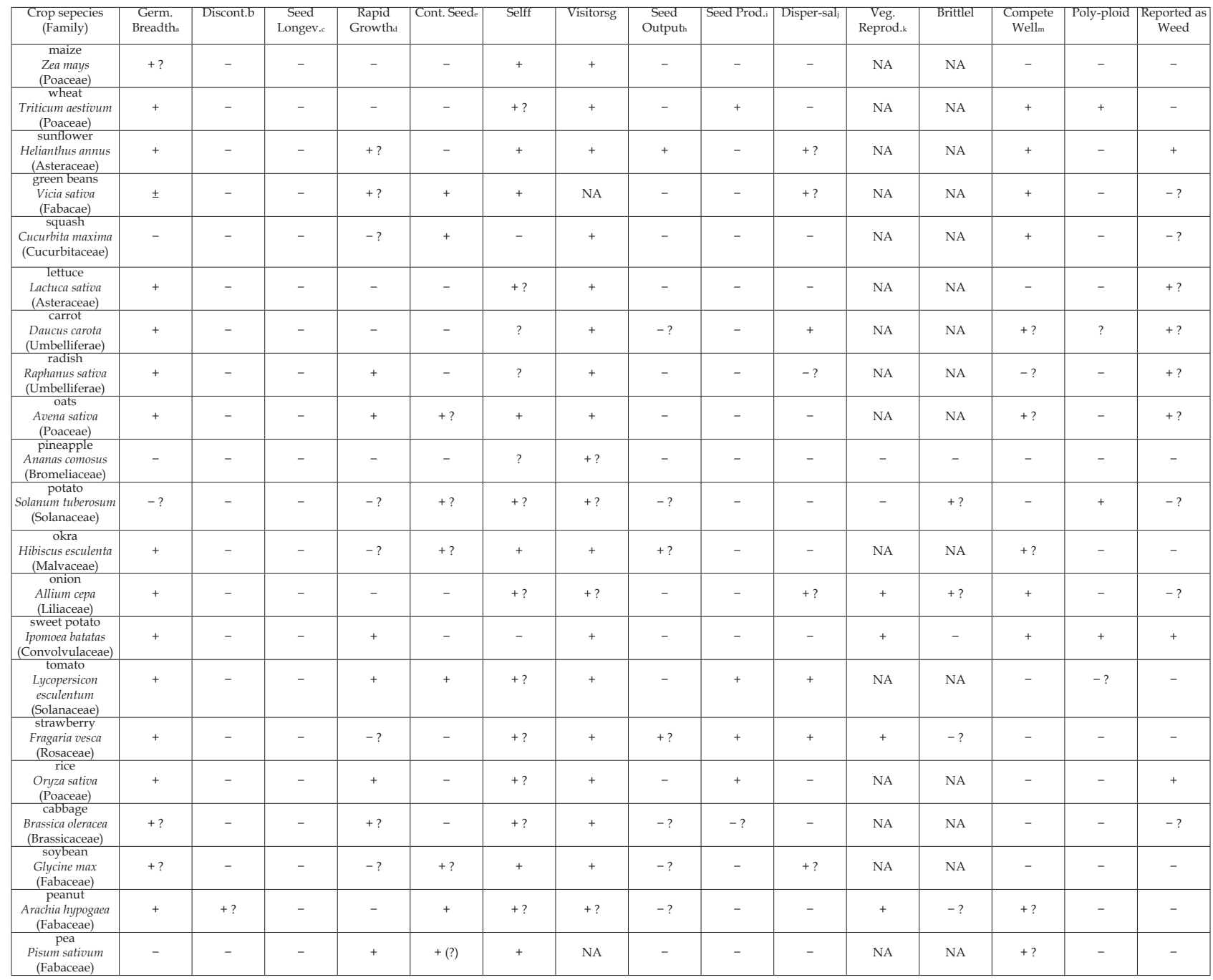

${ }^{a}$ Germination requirements fullilled in many environments; ${ }^{b}$ Internally controlled discontinuous germination; ${ }^{c}$ Long-lived seed; ${ }^{\mathrm{d}}$ Rapid growth to flowering; ${ }^{\mathrm{e} C}$ Continuous seed production as long as growing conditions permit; ${ }^{\mathrm{f}}$ Facultatively self-compatible; ${ }^{\mathrm{g}}$ If outcrossed, uses wind or unspecialized insects; ${ }^{\mathrm{h}}$ Very high seed output possible; iSome seeds produced in many environments: tolerant; 'Seeds adapted for short and long distance dispersal; ${ }^{\mathrm{k}}$ If perennial, vegetative growth or regeneration from fragments; If perennial, hard to uproot; ${ }^{\mathrm{m} G o o d ~ c o m p e t i t o r: ~ r o s e t t e, ~ c h o k i n g ~ g r o w t h, ~ a l l e l o c h e m i c s ; ~}{ }^{n}$ Form ecotypes; Cultivated: 1 , planted as soil binder; 2, cultivated; 3, gathered as potherb; 4, gathered as medicinal plant; 5 , raised as pasture; 6 , used in mats; 7 , not used by humans. 
(plants which, on the average, seriously infest 33 different crops in 54 different countries) $)^{21}$, possess an average of 85.6 percent (std. error 0.12 ) of the characteristics of an ideal weed, i.e. 11 of 13. (This calculation uses only those categories for which the data are satisfying, i.e. omitting the ?s. It treats +/- as +.)

Most of the worst weeds (for which there are data on 12 of the 14 , or 86 percent) form ecotypes, local races that are adapted to local climatic and agricultural conditions. As Brown and Marshall ${ }^{27}$ pointed out, virtually all (16 of 17, 94 percent) are polyploid. In addition, five (29 percent) are currently actively cultivated somewhere in the world, seven (41 percent) are grown as pasture grasses or gathered as food although not cultivated, and one (Convolvulus arvensis) is gathered as a medicinal herb in India. Only four (24 percent) are not reported as being used by humans by Holm et al. ${ }^{21}$.

For the 20 weeds drawn at random from the list of the 47 weeds that are serious but not "worst," the results are generally similar. These weeds possess an average of 81 percent of the weedy characteristics (std. error 0.19 ) or 11 traits, using only characters for which there are data. Nine of the 10 plants for which there is information on ecotypes form ecotypes. Eight of the 13 for which there is information are polyploid. This value differs significantly from that for the world's worst weeds. Four (20 percent) of the random weeds are cultivated, eight (40 percent) are used by humans (grazed, gathered, or used medicinally), seven (35 percent) are not reported to be useful, and on Heliotropium indicum I have no information.

\section{Nonweeds}

The situation for 20 plants drawn from the Biological Flora of the British Isles is quite different. (See reference 32 for the citations in Journal of Ecology for each.) For these plants, the mean percent of the weedy traits possessed per plant is 59 percent (std. error 0.20) for those characters for which data exist. These values are significantly different from those for the worst weeds. Sixteeen of the 19 plants (84 percent) are perennial (compared to 47 percent of the worst weeds and 40 percent of the random weeds), a statistically significant difference. Although the nonweeds are a very small subsample drawn from a large flora, most ecosystems have been shown to contain far more perennials than annuals ${ }^{28}$. The tendency for an annual habit among weeds has been repeatedly noted $16,18,19,27$.

Sixteen of 18 plants from the British Flora for which there is information form ecotypes within Britain which seems similar to the weeds, and is not statistically significantly different. Thirteen of 20 are polyploid or have polyploid races, as compared to 16 of 17 worst weeds and nine of 14 random weeds, again not significantly different.

Finally, the Biological Flora reports that eight species have been cultivated in recent times as crops or as ornamentals, one was cultivated only in the Stone Age, three were reported as not cultivated, and for nine there is no information. Given the nature of the Biological Flora, it is probable that those for which no information on use is given have not been cultivated. Thus, eight are considered used by humans, while the other 12 are not. These values are not significantly different from those for the weeds.

\section{Crop Plants}

For the crop plants (Table 2), the mean proportion of weedy characteristics was 42 percent (std. error 0.14 ) or five of the weedy characters. This value is significantly different from the weeds; it is also significantly different from the sample from the British Flora.

Among the crop plants, six of 20 (30 percent) are polyploid, which is significantly fewer than any othel group. Six crop plants have weedy races, two others have congeners that present weed problems, and the rest do not appear to be weedy. Note that while the majority of the plants in the weed samples are used by humans, the minority of crop plants has escaped to become weeds.

\section{Discussion}

There are significant differences if the distribution of weedy characteristics among weeds, normal plants, and crops. The world's most serious weeds possess on the average 10 or 11 of these characters, a random collection of British plants have an average seven of the traits, and crop plants only five. For the average crop to become as "weedy" as the average weed, it would need to acquire five weedy traits. Even using the 
unlikely assumption that those traits are single loci in which a dominant mutation would provide the weedy character, this would require the simultaneous acquisition of five gene substitutions. Since the probability of multiple mutations is generally the joint probability of single mutations, the probability of changing the average crop to the average weed is $\left(10^{-}\right.$ $\left.{ }^{5}\right)^{5}$, or $10^{-10}$ (ref. 30). Even in the most numerous crop plants (perhaps 18 billion maize individuals are grown annually) this is not very probable. Since most of the crops listed are purchased from seed suppliers and not allowed to propagate, the plants will not gradually add weedy traits. Perennial and self-seeding crops, while more able to accumulate mutants, are generally grown in much smaller numbers. The probability of joint occurrence of new alleles producing significantly weedy plants from most crops is low.

There are several important qualifications to this finding. First, the mean result is only a mean. There is much less difference between the extreme individuals of the different groups. For example, among the weeds, Cirsium arvense (Canada thistle) infests 27 crops in 37 countries but appears to have only six of 12 weedy characteristics while, among the crops, tomatoes (Lycopersicon esculentum) have seven of 13 weedy characteristics, making them "weedier" on this measure than the thistle.

In addition, six of the 20 crop plants (30 percent) have weedy races, and nine of the 37 weeds (24.3 percent) are actively cultivated somewhere-indicating that the two categories actively exchange members. Even if a crop becomes a weed, only because cultivation is discontinued and not through evolution of weediness, a genetically engineered crop will still become a genetically engineered weed.

The recent emergence of a seriously weedy race of millet (Panicum miliace$u m$ ) in Wisconsin and Minnesota after 200-300 years of cultivation in North America without weed problems ${ }^{31}$ emphasizes how much we do not understand about weed evolution. Until such events can be anticipated, there will be an ongoing risk of weeds derived from genetically engineered crops.

This analysis should not be interpreted as a quick fix to problems of the new technology, but rather as directions for case-by-case problem solving. Plants with very low weediness and no weedy relatives are unlikely to be the source of weed populations in the future any more than they have been in the past (e.g., maize, pineapple $)^{2,15,21}$. Plants with high inherent weediness and/or weedy relatives (oats, sunflowers) ${ }^{2,19}$ will, on the other hand, require serious scrutiny if we are to avoid additional problems. Moreover, study of the causes of weed success can suggest methods of modifying crop plants to reduce the risk of weed evolution. For example, infertile plants will have much less risk of producing weeds than fertile plants, due to lack of recombination, gene exchange, and propagules. Other approaches can also be suggested: poor seed longevity, careful management of vegetative reproduction, or dependence on cultivation practices, e.g. a trace mineral or soil disturbance for survival. To some degree, such dependencies already exist and could be exploited.

References

1. United States Congress Office of Technology Assessment. New Developments in BiotechnologyField-Testing Engineered Organisms: Genetic and Ecological Issues. 1988. OTA-BA-350. Washington, D.C. U.S. Government Printing Office.

2. Regulatory Considerations: Genetically Engineered Plants. 1988. Boyce Thompson Institute (ed.), Center for Science Information, San Francisco, Calif.

3. Brill, W. J. 1985. Safety concerns and genetic engineering in agriculture. Science 219: 381

4. Colwell, R. K., Norse, E. A., Pimentel, D., Sharples, F. E., and Simberloff, D. 1985. Genetic engineering in agriculture. Science 229: 115.

5. Davis, B. D. 1987. Bacterial domestication: underlying assumptions. Science 235: 1,329.

6. Sharples, F. E. 1987. Regulation of products from biotechnology. Science 235: 1,329.

7. Keeler, K. H. 1985. Implications of weed genetics and ecology for the deliberate release of genetically engineered crop plants. Recomb. DNA Tech. Bull. 8: 165 .

8. Alexander, M. 1985. Ecological consequences: reducing the uncertainties. Issues Sci. Technol. 1: 57.

9. Coordinated framework for regulation of biotechnology. 1986. Office of Science and Technology Policy. Fed. Reg. 51: 23,301.

10. Hauptli, H., Newell, N., and Goodman, R. M. 1985. Genetically engineered plants: environmental issues. Bio/Technology 3: 437.

11. Furner, I. J., Huffman, G. A., Amasino, D. J., Garfinkel, D. J., Gordon, M. P., and Nester, E. W. 1986. An Agrobacterium transformation in the evolution of the genus Nicotiana. Nature 319: 422.

12. Goodman, R. M. and Newell, N. 1985. Genetic engineering of plants for herbicide resistance: status and prospects, p. 47 in Engineered Organisms in the Environment: Scientific Issues. $\mathrm{H}$. O. Halverson, D. Pramer, and M. Rogul (eds.),
American Society for Microbiology, Washington, D.C.

13. Pimentel, D., Glenister, C., Fast, S., and Gallahan, D. 1982. Environmental risks associated with the use of biological and cultural pest controls. NTIS Report No. PB-83-168716. National Technical Information Service, Springfield, Va.

14. Vitousek, P. M. 1985. Plant and animal invasions: can they alter ecosystem processes? p. 169 in Engineered Organisms in the Environment: Scientific Issues. H. O. Halverson, D. Pramer, and M. Rogul (eds.), American Society for Microbiology, Washington, D.C.

15. DeWet, J. M. J. and Harlan, J. R. 1975. Weeds and domesticates: evolution in the manmade habitat. Econ. Bot. 29: 99.

16. Baker, H. G. 1965. Characteristics and modes of origin of weeds., p. 147 in The Genetics of Colonizing Species. H. G. Baker and G. L. Stebbins (eds.), Academic Press, New York.

17. Baker, H. G. 1974. The evolution of weeds. Ann. Rev. Ecol. Syst. 5: 1.

18. Hill, T. A. 1977. The Biology of Weeds. Institute of Biology. Studies in Biology, Edward Arnold, London.

19. Oka, H.-I. and Morishima, H. 1982. Ecological genetics and the evolution of weeds, p. 73 in $\mathrm{Bi}$ ology and Ecology of Weeds. W. Holmer and N. Numata (eds.), Dr. W. Junk, The Hague.

20. Bazzaz, F. 1986. A life history of colonizing plants. Some demographic, genetic, and physiological features, p. 96 in Ecology of Biological Invasions of North America and Hawaii. SpringerVerlag, New York.

21. Holm, L. G., Plunknett, D. L., Pancho, J. V., and Herberger, H. P. 1977. The World's Worst Weeds: Distribution and Biology. University Press of Hawaii, Honolulu.

22. Rabinowitz, D., Cairns, S., and Dillon, T. 1986. Seven forms of rarity and their frequency in the flora of the British Isles, p. 182 in Conservation Biology: The Science of Scarcity and Diversity. M. S. Soule (ed.), Sinauer, Sunderland, Mass.

23. Harrison, S. G., Masefield, G. B., and Wallis, M. 1969. The Oxford Book of Food Plants. Oxford University Press, London.

24. Thompson, H. C. and Kelly, W. C. 1957. Vegetable Crops (5th edition). McGraw-Hill, New York.

25. Yamaguchi, M. 1983. World Vegetables: Principles, Production, and Nutritive Values. Avi Publishing, Westport, Conn.

26. Bassett, M. J. 1986. Breeding Vegetable Crops. Avi Publishing, Westport, Conn.

27. Brown, A. D. H. and Marshall, D. R. 1981. Evolutionary changes accompanying colonization in plants, p. 351 in Proc. 2nd International Congo Syst. and Evolutionary BioIogy. G. G. E. Scudder and J. L. Reveal (eds.), Hunt Institute for Botanical Documentation, Carnegie-Mellon University, $\mathrm{Pa}$.

28. Risser, P. G., Birney, E. C., Blocker, H. D., May, S. W., Parton, W.J., and Weins, J. A. 1981. The True Prairie Ecosystem. Hutchinson Ross Publishing, Stroudsburg, Pa.

29. Silander, J. A., Jr. 1985. Microevolution in clonal plants, p. 107 in Population Biology and Evolution of Clonal Organisms. J. B. C. Jackson, L. W. Buss, and R. E. Cook (eds.), Yale University Press, New Haven, Conn.

30. Lewin, B. 1987. Genes (3rd edition), Wiley, New York.

31. Cavers, P. B. and Bough, M. A. 1985. Proso millet (Panicum miliaceum L.): a crop and a weed, $\mathrm{p}$. 143 in Studies on Plant Demography. A Festschrift for John L. Harper, Academic Press, New York.

32. The following citations are all from the Journal of Ecology: 1948, 36: 203; 1953, 41: 447; 1955, 43: 331; 1956, 44: 677; 1957, 45: 289; 1959, 47: 169; 697; 1962, 50: 235; 1963, 51: 227; 733; 1964, 52: 709; 1966, 54: 795; 196. 